\title{
LABORATORY ASSESSMENTS AND FIELD TESTS IN PREDICTING COMPETITIVE PERFORMANCE OF SWIMMERS
}

\author{
Ilona Judita Zuozienè, Jonas Poderys \\ Lithuanian Academy of Physical Education, Kaunas, Lithuania
}

\begin{abstract}
Research background and hypothesis. The assessments of functional fitness of swimmers includes the analyses of the physical, physiological and biomechanical indices for scientific purposes. The hypothesis is that dynamical parameters registered while performing field testing tasks could be more informative than laboratory assessments in predicting the performance abilities.

The aim of the study was to compare the informativeness of field tests and laboratory assessments in predicting the possible performance of athletes in the $50 \mathrm{~m}$ distance.

Research methods. Twelve professional swimmers took part in three testing procedures. First, each participant performed a test in water to establish the traction force parameters and indices of muscle power and anaerobic capacity. Second, the subjects performed a control $50 \mathrm{~m}$ freestyle swim the best they could. Third, the indices of relative muscle power during jumping tasks, anaerobic capacity, and functional indices of cardiovascular system were assessed during laboratory testing.

Research results. Significant correlation was found between the results in $50 \mathrm{~m}$ swimming and traction forces while performing testing tasks in water or out of water with arms or arms and legs together. However, there was no statistically significant correlation between the results in swimming and the height of vertical jump. Still there exists significant correlation $(\mathrm{p}<0.05)$ between the speed and force components as well as fatigability index and the competition result $(\mathrm{r}=-0.47 ; \mathrm{r}=0.56$ and $\mathrm{r}=0.67$, respectively).

Discussion and conclusions. Dynamical parameters measured in the swimming pool while performing field tests are more suitable than the data of laboratory research for predicting the results of swimmers in the $50 \mathrm{~m}$ freestyle swim. The vertical high jump tests and indices of ECG allow distinguishing the factors limiting the working capacity of athletes.
\end{abstract}

Keywords: swimming, functional fitness, field test.

\section{INTRODUCTION}

$\mathrm{V}$ arious methodological approaches could be applied in assessing the level of fitness and functional state of athletes as well as in predicting their performance (Noakes, 2002; Barbosa et al., 2010; Cortesi et al., 2010). Still the specific nature of the various kinds of sports is a significant factor in selecting tests and control exercises (Bosco et al., 1983; Counsilman, 1982; Carl et al., 2010; Cortesi et al., 2010). Therefore, adapted tests, i. e. tests when the workload given during the testing corresponds to the specific manner of the sports action, are far more suitable for assessing special fitness of athletes in any kind of sports. The aim of this study was to compare the informativeness of field tests (testing indices obtained in the swimming-pool) and laboratory assessments for predicting the competitive performance of swimmers in the $50 \mathrm{~m}$ distance. 


\section{RESEARCH METHODS}

The participants of the study were 12 male swimmers (age $-18.63 \pm 0.6$ years, body mass $72.6 \pm 2.57 \mathrm{~kg}$ ). All swimmers were of Lithuanian national category level, specializing in sprint and middle distances (50, 100 and $200 \mathrm{~m}$ ). The participants of the study took part in three testing procedures.

The first testing procedure consisted of establishing the indices of muscle power and anaerobic capacity with special field tests being applied. Maximum traction out of water in isometric regime in the middle of the pull $\left(\mathrm{F}_{\mathrm{o}}\right)$; pulling force in water in tethered swimming: a) swimming by hand movements $\left(\mathrm{F}_{\mathrm{h}}\right)$; b) swimming by leg movements $\left(F_{1}\right)$ and c) swimming by absolutely coordinated movements of hands and legs $\left(F_{c}\right)$ were investigated. On the basis of the measuring obtained, such relative indices as relative traction out of water $\left(\mathrm{F}\right.$ (relat.) $=\mathrm{F}_{\mathrm{o}}$ body mass); relative pulling force in water $\left(\mathrm{Fw}\right.$ (relat.) $=\mathrm{F}_{\mathrm{c}} /$ body mass); force realization index $\mathrm{FI}=\mathrm{F}_{\mathrm{c}} / \mathrm{F}_{\mathrm{o}} \times 100 \%$ and force coordination index $\left(\mathrm{FCI}=\mathrm{F}_{\mathrm{c}} /\left(\mathrm{F}_{\mathrm{h}}+\mathrm{F}_{\mathrm{l}}\right)\right.$ $\mathrm{x} 100 \%$ ) were calculated. Performing swimming test with the duration of $30 \mathrm{~s}$, the maximum force (Fmax and F30) generated in the distance and force endurance index (FEI30s = F30/Fmax x 100\%) were calculated.

The second testing procedure consisted in the $50 \mathrm{~m}$ freestyle striving for maximum performance. The third testing procedure was aimed at assessing the working capacity and functional condition of swimmers with laboratory tests being applied. The program of laboratory research consisted of assessment of the indices of speed and force components of muscular contraction, power and anaerobic working capacity during the jumping tests (Poderys et al., 2008), as well research done in the functional condition of the body applying the computerized system "Kaunas-load" designed for the registration and analysis of 12-leads electrocardiogram (ECG). All jumping tasks were performed on the contact plate that allowed registering changes in the height and power of the jumps performed and to calculate the values of speed and force components (Poderys et al., 2007). The ECG was reordered continuously during 30 -s vertical jump test and the next indices were taken for analysis: $\mathrm{HR}_{\max }, \mathrm{JT}_{\max }$, $\mathrm{ST}$ segment depression $\mathrm{JT}_{\text {recovery }}$ during the first 2 minutes after workload, index of $\mathrm{PWC}_{170}$ and integral index of body functional state. The integral index of functional state was calculated according the dynamics or HR, JT interval and muscular performance during the testing workload (Vainoras, 2002).

In the process of the analysis of research results, correlations between the performance results achieved in the $50 \mathrm{~m}$ swim and other indices of were analysed.

\section{RESEARCH RESULTS}

The data obtained during the study showed that for predicting the results of swimmers in the $50 \mathrm{~m}$ freestyle, the results in field tests were the best predictors of competitive performance compared to those of laboratory research (Table). Though a greater number of indices were registered during the research carried out (indices are given in "Research Methods"), Table contains indices having logical meaning and significant for the substantiation of the conclusions formulated in the present paper. Smaller in extent but still statistically

\begin{tabular}{|c|c|c|c|c|c|c|}
\hline \multirow{4}{*}{$\begin{array}{l}\text { Table 1. Correlation } \\
\text { values between the } \\
\text { result achieved by } \\
\text { the subjects in the } \\
50 \mathrm{~m} \text { swim and other } \\
\text { indices of fitness or } \\
\text { functional state }\end{array}$} & \multicolumn{6}{|c|}{ FIELD RESEARCH (TESTS IN THE SWIMMING POOL) } \\
\hline & \multirow{2}{*}{$\begin{array}{c}\text { Traction out } \\
\text { of water }\end{array}$} & \multicolumn{3}{|c|}{ Pulling force in water } & \multicolumn{2}{|c|}{ 30-s swimming test } \\
\hline & & $\mathbf{F}_{\mathbf{h}}$ & $\mathbf{F}_{1}$ & $\mathbf{F}_{\mathbf{c}}$ & $\mathrm{F}_{\max 30 \mathrm{~s}}$ & FEI $_{30 \mathrm{~s}}$ \\
\hline & $-0.71 *$ & $-0.84 *$ & 0.23 & $-0.66^{*}$ & $-0.74 *$ & $-0.76^{*}$ \\
\hline & \multicolumn{6}{|c|}{ INDICES OF VERTICAL JUMPS } \\
\hline & Jump height & \begin{tabular}{|c|} 
Relative \\
muscle power
\end{tabular} & $\begin{array}{c}\text { Speed } \\
\text { component }\end{array}$ & $\begin{array}{c}\text { Force } \\
\text { component }\end{array}$ & $\begin{array}{c}\text { Anaerobic } \\
\text { working capacity }\end{array}$ & $\begin{array}{c}\text { Fatigability during } \\
\text { 30-s jumps }\end{array}$ \\
\hline & 0.13 & 0.21 & $0.47 *$ & $0.56 *$ & $-0.52 *$ & $0.67 *$ \\
\hline & \multicolumn{6}{|c|}{ ECG INDICES DURING ANAEROBIC 30-s WORKLOAD } \\
\hline Note. $*$ - statistically & $\mathrm{HR}_{\max }$ & $\mathrm{JT}_{\max }$ & $\begin{array}{c}\text { ST segment } \\
\text { depression }\end{array}$ & $\mathrm{JT}_{\text {recovery }}$ & $\mathrm{PWC}_{170}$ & $\begin{array}{c}\text { Integral } \\
\text { assessment }\end{array}$ \\
\hline $\begin{array}{l}\text { Significant values of the } \\
\text { correlation }(\mathrm{p}<0.05) \text {. }\end{array}$ & 0.14 & -0.26 & 0.07 & $-0.47 *$ & $-0.33 *$ & $-0.42 *$ \\
\hline
\end{tabular}


significant was the correlation between the result achieved in the $50 \mathrm{~m}$ swim and some relative indices investigated, i. e. relative pulling force in water $(r=-0.56, p<0.05)$, relative traction out of water FCI $(r=0.59, p<0.05)$. Correlation values presented in the Table indicate that field tests, i. e. the results of measuring and tests done, report athletic fitness more precisely than the data of laboratory research, as well as their possibilities to achieve high results in the $50 \mathrm{~m}$ swim.

The results of the present research, however, should no statistically significant correlation between the result in swimming and the height of the vertical jump $(r=0.13, p>0.05)$. Still there exists significant correlation $(\mathrm{p}<0.05)$ between the speed and force components as well as fatigability index and the competition result $(\mathrm{r}=-0.47 ; \mathrm{r}=0.56$ and $r=0.67$, respectively).

\section{DISCUSSION}

Field tests are carried out under the natural conditions and in sport they are used to analyse the effects of training, for talent identification, measuring an athlete's physiological capabilities and functional state (Young, 2001). The results obtained during this study showed that field tests, i. e. the results of measuring and tests done in the swimming pool, are more suitable than the data of laboratory research for predicting the results of swimmers in the $50 \mathrm{~m}$ freestyle swim. No doubt, such result was expected, but the main interest of this study was to compare the informativeness of various laboratory measurements.

Testing and measurement, are the means of collecting information upon which the performance evaluations and decisions should be done, but in the analysis it is necessary to take into account the factors that may influence the results. On the one hand, the sports results and their dynamics are the best indices of performance abilities of athletes, but on the other hand, not in all athletic events this approach could be applied in practice for themanagement of training (Young, 2001; Winter et al., 2007). Various testing procedures and various indices were applied for these purposes. Analysis of factors determining sports performance supports the notion that the power of muscular contraction is very important for the fast performance of push-up during the start (Counsilman, 1982; Barbosa et al., 2010; Cortesi et al., 2010). On the other hand, leg muscles make the greatest part of the whole muscle mass of the body. Thus it is believed that their force and speed estimates show the effect generated by these muscles and thus are one of the main factors determining effective swimmer start and all sports performance (Cortesi et al., 2010; Douda et al., 2010). The simplest and most frequently used index of explosive force is the maximal height of vertical jump (Christopher, 2000). Applying tests of vertical jumps allows one to easily adapt oneself to the obligatory metrological requirements (Bosco et al., 1983; Maud, Foster, 1995; Christopher, 2000; Poderys et al., 2007). The results of the present research, however, showed no statistically significant correlation between the result in swimming and the height of the vertical jump. Still there exists correlation between speed and force components, as well as fatigue index, and the competition result - these indices are significant and should be taken into account when performing laboratory research in the functional condition and fitness of swimmers.

The computerized ECG registration and analysis system Kaunas-load" have been applied for a long time for the assessment of functional fitness and functional state of members and candidates to the Lithuanian Olympic team of various kinds of sport, including swimmers (Korsakas et al., 2002; Poderys, 2003; Ezerskis, 2009). This system enables one to register a lot of functional indices of cardiovascular system during workloads and to carry out the integral assessment, as well as to perform the standardized assessment of important ECG indices. The present research pursued a specific and relatively narrow task, i.e. to assess the possibilities of athletes in the $50 \mathrm{~m}$ swim. It was only separate indices of CVS that correlated with the results shown in the $50 \mathrm{~m}$ swim to a smaller extent than the indices registered in the swimming-pool (Table). One cannot make absolute generalizations and assert, however, that these indices are of less importance. Function fitness of supplying systems is important in the events of all kinds of sports (Maud, Foster, 1995; Spencer et al., 1996; Vainoras, 2002). Comparing the results obtained in the process of our research or, to be more exact, the cardiovascular indices of the swimmers who showed the best and the worst results the individual differences in the indices of PWC170, the index of integral assessment, adaptation to the speed of the loads undertaken, the maximum change between the JT interval of ECG and the RR interval relation when performing vertical jumps for 30 -s, as well as change in the JT interval and its recovery during the first two minutes were established. In general, the indices registered by the ECG registration and analysis 
system "Kaunas-load" allowed distinguishing out the single and individual factors limiting the working capacity of athletes and providing individual recommendations aimed at managing the process of training.

\section{CONCLUSIONS AND PERSPECTIVES}

1. Field tests, i. e. the results of measuring and tests done in the swimming pool, are more suitable than the data of laboratory research in predicting the results of swimmers in the $50 \mathrm{~m}$ freestyle swim.

2. The tests of vertical high jump used in assessing the power of muscular contractions do not allow predicting the possibilities of swimmers to achieve good results in the $50 \mathrm{~m}$ swim. Still there exists correlation between speed and force components, as well as fatigue index and the competitive result - these indices are significant and should be taken into account when performing laboratory assessment of fitness for swimmers.

3. The dynamics of separate indices of ECG allows distinguishing the factors limiting the working capacity of athletes and providing individual recommendations important for the management of the training process. However, no significant correlation was found between integral or separate indices of cardiovascular system and swimming performance in $50 \mathrm{~m}$ swim.

\section{REFERENCES}

Barbosa, A., Dopsaj, M., Okicic, T., Andries Júnior, O. (2010). The usefulness of the fully tethered swimming for $50-\mathrm{m}$ breaststroke performance prediction. XIth International Symposium for Biomechanics and Medicine in Swimming: Program \& Book of Abstracts (p. 85). Oslo: Norwegian School of Sport Science.

Bosco, C., Luhtanen, P., Komi, P. (1983). A simple method for measurement of mechanical power in jumping. European Journal of Applied Physiology, 50, 273-282.

Carl, D. L., Leslie, N., Dickerson, T., Griffin, B., Marksteiner, A. (2010). Correlation between dry land strength measurements and in water force generation. XIth International Symposium for Biomechanics and Medicine in Swimming: Program \& Book of Abstracts (p. 112). Oslo: Norwegian School of Sport Science.

Christopher, J. (2000). Physiological Tests for Elite Athletes. Australian Sports Commission. USA: Human Kinetics.

Cortesi, M., Cesaracciu, E, Sawacha, Z, Gatta, G. (2010). Which is the recommended duration for the tethered swimming test? XIth International Symposium for Biomechanics and Medicine in Swimming: Program \& Book of Abstracts (p. 91). Oslo: Norwegian School of Sport Science.

Counsilman, J. E. (1982). Sports Swimming (in Russian). Moscow.

Douda, H., Toubekis, A., Georgiou, C., Gourgoulis, V., Tokmakidis, S. P. (2010). Predictors of performance in pre-pubertal and pubertal male and female swimmers. XIth International Symposium for Biomechanics and Medicine in Swimming: Program \& Book of Abstracts (pp. 129-130). Oslo: Norwegian School of Sport Science. Ežerskis, M. (2009). Didelio meistriškumo graikuromènu imtynininku širdies ir kraujagysliu sistemos funkciniu rodikliu kaita metiniame treniruotes cikle: daktaro disertacija. Kaunas: LKKA.

Korsakas, S., Vainoras, A., Gargasas, L., Poderys, J., Jurkonis, V. (2002). Telecardiology system: Methods and evaluation of the effects of adaptation of Lithuania's highly-skilled athletes to conditions of Australia. Education, Physical Training, Sport, 3, 19-22.

Maud, P. J., Foster, C. (1995). Physiological Assessment of Human Fitness. USA: Human Kinetics.

Noakes, T. D. (2000). Physiological models to understand exercise fatigue and the adaptations that predict or enhance athletic performance. Scandinavian Journal of Medicine and Science in Sports, 10, 123-145. Poderys, J., Buliuolis, A., Poderienè, V., Norkus, S. (2007). Kompiuterinè programa „Šuolių testai“ vertinti moksleivių, studentų ir didelio meistriškumo sportininkų raumenų funkcinius gebėjimus. Biomedicinine inžinerija. XI darbu rinkinys: tarptautinès konferencijos pranešimu medžiaga (pp. 80-84). Kaunas: KTU leidykla.

Poderys, J. (2003). Sportininko būsenos vertinimai, teikiant operatyvią informaciją per Atènu olimpines žaidynes, panaudojant kompiuterinę EKG analizès sistemą "Kaunas-krūvis" bei kineziologinè judejjimo ir judesių charakteristiku monitoravimo sistemą. Programos “Atènai-2004" igyvendinimas (pp. 23-24). Vilnius: LTOK.

Spencer, M. R., Gastin, P. B., Payne, W. R. (1996). Energy system contribution during 400 to 1500 metres running. New Studies in Athletics, 17 (4), 59-65.

Vainoras, A. (2002). Functional model of human organism reaction to load - evaluation of sportsman training effect. Ugdymas. Kūno kultūra. Sportas, 3, 88-93.

Winter, E. M., Jones, A. M., Davison, R. S., Bromley, P. D., Mercel, P. H. (2007). Sport and Exercise Physiology Testing Guidelines. London: Routlege.

Young, M. (2001) Test decathlon for the evaluation of track and field athletes. Track Coach, 156, 4985-4987.

Zuozienė, I. J., Kriščiukaitis, A., Muckus, K. (2005). Kompiuterizuota dinamografinè sistema plaukikų specialiosios jègos parametrams tirti. Ugdymas. Küno kultūra. Sportas, 2 (56), 63-69. 


\title{
PLAUKIKŨ VARŽYBINĖS VEIKLOS PROGNOZAVIMAS PAGAL LABORATORINIU TYRIMU IR SPECIALIŲJŲ TESTUU REZULTATUS
}

\author{
Ilona Judita Zuozienè, Jonas Poderys \\ Lietuvos kūno kultūros akademija, Kaunas, Lietuva
}

\begin{abstract}
SANTRAUKA
Tyrimo pagrindimas ir hipotezé. Plaukikų parengtumui vertinti praktikoje ir moksliniu tyrimų metu dažnai analizuojami fizinių ir funkciniu galių, techninio parengtumo rodikliai. Tyrimu tikrinama hipotezè, kad dinaminių ir funkcinių rodiklių tyrimas adaptuotais testais specifinèmis sąlygomis yra informatyvesnis už laboratorinius tyrimus prognozuojant pasiekimų galimybes sprinto rungtyse.

Tikslas - palyginti adaptuotų praktinių testų (tyrimų, atliekamų baseine) ir laboratorinių tyrimų informatyvumą prognozuojant plaukiku $50 \mathrm{~m}$ nuotolio rezultatus.

Metodai. 12 profesionaliu plaukikų vyrų tirti tris kartus: pirmą kartą traukio jẻgos ir anaerobinio darbingumo rodikliai buvo nustatomi kompiuterizuota dinamografine sistema plaukiant; antrą $-50 \mathrm{~m}$ plaukiama laisvuoju stiliumi siekiant maksimalaus rezultato; trečią - ivvertintas plaukiku darbingumas ir funkcinė būklè atliekant laboratorinius tyrimus.

Rezultatai. Tyrimas parodè, kad reikšmingai su $50 \mathrm{~m}$ plaukimo rezultatu koreliavo traukio jèga tiriant sausumoje, traukio jèga vandenyje plaukiant vien rankomis, visiškai suderintais rankų ir kojų judesiais, 30 s plaukimo testo metu pasiekta maksimaliaja traukio jèga. Koreliacija tarp plaukimo rezultato ir vertikalaus šuolio aukščio rodiklių nebuvo reikšminga, tačiau reikšmingai $(\mathrm{p}<0,05)$ koreliavo plaukimo rezultatas su jẻgos ir greitumo komponentais bei raumenų nuovargio rodikliu $(\mathrm{r}=-0,47 ; \mathrm{r}=0,56$ ir $\mathrm{r}=0,67$ atitinkamai).

Aptarimas ir išvados. Plaukiku, plaukiančių $50 \mathrm{~m}$ laisvuoju stiliumi, rezultatams prognozuoti tinkamesni yra baseine atliktų testų ir matavimų rezultatai, nei laboratorinių tyrimų duomenys. Vertikalių šuolių testai ir EKG rodikliai yra naudotini vertinant plaukikų parengtumą ir funkcinę būklę, išskiriant darbingumą ribojančias grandis.
\end{abstract}

Raktažodžiai: plaukimas, funkcinis parengtumas, specialieji testai. 